\title{
PIENIĄDZ MIĘDZYNARODOWY W POWOJENNEJ HISTORII MIĘDZYNARODOWEGO SYSTEMU WALUTOWEGO TEORIA I PRAKTYKA
}

\begin{abstract}
Streszczenie. Celem artykułu jest omówienie dyskusji na temat istoty, form i mechanizmów pieniądza międzynarodowego. W artykule przedstawiono ewolucję głównych form waluty światowej oraz zbadano korzyści i zagrożenia wynikające z senioratu walutowego.

Słowa kluczowe: system waluty złotej, dolar, waluta międzynarodowa, waluta kluczowa, system z Bretton Woods.
\end{abstract}

\section{WPROWADZENIE}

Jednym z najważniejszych problemów współczesnych finansów światowych jest pieniądz międzynarodowy. Od tego, jak pełni swoje funkcje, zależy sprawność międzynarodowego systemu walutowego. Powtarzające się kryzysy finansów międzynarodowych są konsekwencjami ułomności współczesnego pieniądza światowego.

W światowej literaturze ekonomicznej brakuje opracowania, w którym w ujęciu teoretycznym i praktycznym poddano by analizie istotę i funkcje pieniądza międzynarodowego oraz związane z nim mechanizmy. Jest rzeczą charakterystyczną, że intensyfikowanie badań dotyczących waluty światowej następuje w czasach kryzysów i przeobrażeń w globalnej gospodarce. Wtedy to politycy i ekonomiści zgłaszają liczne projekty reform międzynarodowego systemu walutowego. W powojennej historii finansów światowych możemy wyodrębnić trzy takie okresy:

1. Lata 1944-1946 to czas ożywionej dyskusji na temat założeń powojennego systemu walutowego i roli złota oraz głównych walut.

2. Przełom lat 60. i 70. XX w. to okres najpoważniejszego kryzysu dolara po II wojnie światowej, problemów z utrzymaniem stałej ceny złota w walucie USA oraz utworzenia SDR.

3. Początek XXI w. - powstanie euro i wprowadzanie wspólnej waluty na światowe rynki finansowe.

* Uniwersytet Łódzki, Wydział Ekonomiczno-Socjologiczny, Katedra Międzynarodowych Stosunków Gospodarczych. 
Badania i dyskusje dotyczące pieniądza międzynarodowego, toczone w literaturze ekonomicznej oraz na forach organizacji międzynarodowych, zaowocowały powstaniem licznych projektów reformy międzynarodowego systemu walutowego. Część z nich została wdrożona i w istotny sposób wpłynęła na kształt współczesnych finansów międzynarodowych, natomiast inne pozostały niezrealizowane. Będzie o nich mowa w dalszej części artykułu.

Nadal aktualne są kluczowe problemy związane z międzynarodowym systemem walutowym. Do dziś nie potrafimy udzielić odpowiedzi na najważniejsze pytania:

1. Czy gospodarka światowa potrzebuje pieniądza międzynarodowego, podstawy porządku walutowego, czy też może funkcjonować jako system wielodewizowy? Czy możliwe jest oparcie finansów światowych na dwóch-trzech walutach kluczowych?

2. Czy pieniądzem międzynarodowym powinno być złoto, jednostki międzynarodowe czy pojedyncze waluty najważniejszych państw świata?

3. Jakie mechanizmy lub organizacje międzynarodowe powinny określać poziom podaży pieniądza światowego?

4. Jak działa seniorat walutowy, czy jest to exorbitant privilege, czy też przekleństwo kraju emitującego walutę światową?

5. Czy rodzaj pieniądza międzynarodowego, jego charakter i funkcje konstytuują zasady i organizacje systemu walutowego, czy zależność jest odwrotna?

Wymienione powyżej kwestie należą - moim zdaniem - do kluczowych problemów finansów międzynarodowych. Pozostaje jeszcze cały szereg zagadnień powiązanych z funkcjonowaniem pieniądza międzynarodowego, dotyczące chociażby powstawania nierównowag globalnych czy systemu kursów walutowych.

Celem artykułu jest omówienie dyskusji toczącej się w aspekcie kształtowania się powojennego porządku walutowego oraz genezy współczesnego pieniądza międzynarodowego. W toku analiz podjęta będzie próba odpowiedzi na powyżej sformułowane pytania.

W badaniu przedstawiona została ewolucja funkcji i mechanizmów monetarnych różnych form pieniądza międzynarodowego, takich jak złoto, waluty kluczowe czy międzynarodowe jednostki monetarne.

W tym miejscu należy wyjaśnić zakres pojęciowy używanych w pracy terminów, takich jak: „pieniądz światowy” (world money), „waluta międzynarodowa” (international currency), „waluta kluczowa” (key currency), „waluta rezerwowa” (reserve currency) czy „międzynarodowa jednostka walutowa” (international currency unit).

Termin ,pieniądz światowy” został wprowadzony do literatury w okresie międzywojennym i tą nazwą było określane złoto. Po II wojnie światowej, w okresie bezwzględnej dominacji dolara w systemie z Bretton Woods (do połowy lat 60.), waluta amerykańska pełniła funkcję pieniądza światowego. Od końca lat 60. termin ten bardzo rzadko jest używany w literaturze ekonomicznej. 
Pojęcie „waluty kluczowej” powstało w toku dyskusji toczonych pod koniec wojny na temat pieniądza światowego. J. H. Williams uważał, że dolar lub inne waluty tylko zastępują złoto w funkcjach monetarnych (Williams 1943: $645 \mathrm{i} \mathrm{n}$.). Dlatego też nie należy używać wobec nich terminu „waluta światowa” (więcej na ten temat $\mathrm{w}$ dalszej części artykułu). W literaturze pojęcia „waluta kluczowa" i ,waluta rezerwowa" były używane wymiennie - wynikało to z faktu, że po II wojnie światowej zastępowanie złota przez waluty narodowe w funkcji rezerw było jednym z najważniejszych problemów finansów międzynarodowych. Od połowy lat 70. termin ten stopniowo znika z dyskusji o międzynarodowych stosunkach walutowych. Upowszechniło się natomiast pojęcie „waluta międzynarodowa”. Czym różni się ona od „pieniądza światowego” i „waluty kluczowej”?

Po pierwsze, równocześnie może funkcjonować kilka walut międzynarodowych, natomiast pieniądz światowy / waluta kluczowa jest tylko jedna. Po drugie, waluta międzynarodowa może pełnić swe funkcje monetarne w określonych regionach świata (waluty regionalne), zaś pieniądz światowy ma charakter globalny. Po trzecie, waluta międzynarodowa nie musi pełnić wszystkich funkcji monetarnych, a pieniądz światowy - tak.

W opracowaniu będę się starał zachować przedstawioną powyżej dystynkcję znaczenia terminów.

\section{ZŁOTO JAKO PIENIĄDZ ŚWIATOWY}

Złoto pełniło funkcję pieniądza światowego prawdopodobnie od czasów Krezusa (ok. 550 r. p.n.e.), wówczas to król Lidii wpadł na pomysł stemplowania monet, gwarantując ich wagę. Monety były wykonane z elektronu - naturalnego stopu złota i srebra.

Jest rzeczą charakterystyczną, że przez 25 wieków (do I wojny światowej) nikt nie nazywał złota pieniądzem światowym czy walutą międzynarodową. Złoto po prostu było podstawą i miarą systemów pieniężnych, uniwersalnym pieniądzem.

W nowożytnej historii gospodarczej świata najlepszy czas złota to lata 1870-1914, okres funkcjonowania waluty złotej. Dla goldstandardu odpowiedzi na pytania sformułowane we wstępie niniejszego artykułu były oczywiste. Złoto pełniło funkcję podstawy systemu integrującego narodowe systemy pieniężne ${ }^{1}$. Relacje miedzy walutami krajowymi a złotem były stałe. Zdaniem B. T. McCalluma oznacza to, że funt, frank, lir czy dolar były w gruncie rzeczy różnymi nazwami dla określonej ilości złota (McCallum 1996: 72).

Według wielu ekonomistów złoto świetnie pełniło funkcję pieniądza światowego, ponieważ nie miało „narodowości”. Nie było podporządkowane żadnej

${ }^{1}$ W XIX i XX w. nie istniał w czystej (homogenicznej) postaci system waluty złotej, w którym cyrkulowałyby tylko złote monety. Pieniądze krajowe „reprezentowały” złoto (Hayek 1937: 8). 
władzy krajowej czy międzynarodowej. Stabilność goldstandardu wynikała z obowiązującej zasady podaży złota w skali międzynarodowej. Była ona skorelowana ze wzrostem światowego PKB, handlu zagranicznego i cen (Drabowski 1988: 80).

Najbardziej istotna zaleta goldstandardu oraz złota jako pieniądza międzynarodowego to znakomite, symetryczne działanie mechanizmu wyrównawczego, pozwalającego krajom należącym do systemu przywracać równowagę zewnętrzną 2 .

Najważniejszą walutą omawianego okresu był funt brytyjski, który pełnił funkcję (używając współczesnej terminologii) waluty międzynarodowej. O pozycji funta świadczą dane dotyczące gospodarki brytyjskiej. Wielka Brytania importowała (w 1890 r.) 20\% światowego eksportu, natomiast w latach 1860 1914 ok. $60 \%$ handlu światowego było fakturowane w funtach. W 1899 r. $64 \%$ światowych rezerw tworzyły funty, w 1913 r. - 48\% (Eichengreen 2007). Rynek brytyjski stanowił centrum finansowe świata. Weksel „ciągniony na Londyn”, po akceptacji londyńskiego banku, był synonimem wypłacalności.

O umiędzynarodowieniu brytyjskiej gospodarki świadczy fakt, że na przełomie XIX i XX w. eksport kapitału z tego kraju osiągnął ok. 10\% PKB. Cechą szczególną funta jako waluty międzynarodowej było utrzymywanie się (poza nielicznymi epizodami) przez dziesięciolecia bardzo niskich i stabilnych stóp procentowych; długoterminowe wahały się w granicach 3,0-3,2\% (Homer, Sylla 2005: 190 i n.). Przedstawioną sytuację można podsumować następująco: złoto było w latach 1870-1914 pieniądzem światowym, a funt pełnił funkcję pieniądza międzynarodowego. Zadecydowały o tym względy techniczne oraz ekonomiczne - taniej i łatwiej było posługiwać się walutą brytyjską niż złotem.

Podsumowując, należy stwierdzić, że zasady działania międzynarodowego systemu walutowego były pochodną cech i funkcji złota jako pieniądza światowego. Goldstandard nie był skodyfikowany żadną umową międzynarodową, lecz działał dobrze, ponieważ kraje przestrzegały zwyczajów i niepisanych reguł odnoszących się do złota. W okresie późniejszym próbowano rekonstruować system waluty złotej, równocześnie ograniczając funkcje monetarne tego kruszcu - były to próby zdecydowanie nieudane.

\subsection{Pozycja zlota w systemie z Bretton Woods}

W powojennym systemie walutowym monetarne funkcje złota zostały poważnie ograniczone. Na mocy statutu MFW złoto miało być podstawą systemu na równi z dolarem. Oznaczało to, że złoto powinno pełnić funkcje aktywu rezerwo-

\footnotetext{
${ }^{2}$ Działanie symetryczne oznacza, że w równym stopniu dotyczy krajów deficytowych i nadwyżkowych.
} 
wego, środka płatności i miernika wartości. W praktyce jednak złoto było jedynie aktywem rezerwowym. Funkcje miernika wartości (denominatora reżimów kursowych) oraz środka rozliczeń miały charakter wyłącznie tytularny, bez znaczenia praktycznego. Kraje członkowskie MFW wyznaczały parytety swych walut w złocie i w dolarze, jednak w praktyce znaczenie miał tylko parytet dolarowy. Wynikało to z faktu, że nie funkcjonowały prywatne rynki złota, zaś swoboda transferu kruszcu między krajami była bardzo ograniczona. Złoto było używane do rozliczeń - tylko w określonych przypadkach - między państwami a MFW.

Historia złota w powojennym systemie walutowym była bardzo burzliwa, a główne kraje świata i MFW prowadziły bardzo niekonsekwentną politykę wobec złota. Ekonomiczne dzieje złota po 1944 r. można podzielić na kilka okresów:

1. Lata 1944-1971 - czas zdecydowanej obrony przez MFW i główne kraje Zachodu pozycji złota $\mathrm{w}$ systemie.

2. Okres 1971-1978 - intensywne, demonstracyjne eliminowanie złota z funkcji monetarnych.

3. Lata 1980-2014 - czas odbudowy roli złota w funkcji aktywu rezerwowego i prywatyzacja złota. Powrót banków centralnych na prywatny rynek złota.

Od zakończenia II wojny światowej do $1968 \mathrm{r}$ cena złota utrzymywała się na stałym poziomie 35 USD za uncję. Było to konsekwencją silnej pozycji dolara i gospodarki amerykańskiej. W Forcie Knox w połowie lat 40. przechowywane było $70 \%$ światowych zasobów złota monetarnego.

Lata 40. i 50. XX w. to okres tzw. „głodu dolarowego” w Europie. Dolar był bardziej cenionym składnikiem płynności międzynarodowej i rezerw niż złoto. Ten stan rzeczy sprawiał, że kraje MFW nie nadużywały prawa konwersji dolara w złoto (wyjątkiem była Francja).

Sytuacja zmieniła się w latach 60 .,kiedy reaktywowano prywatne rynki złota. Wtedy okazało się, że oficjalna cena żółtego kruszcu jest zaniżona w stosunku do ceny transakcji prywatnych. Presja rynkowa zmusiła System Rezerwy Federalnej (Fed) i banki centralne Europy Zachodniej do interwencji na prywatnych rynkach złota.

W 1961 r. działania te zostały zinstytucjonalizowane - utworzono tzw. „pool złota”. Celem jego funkcjonowania było stabilizowanie ceny tego kruszcu na rynku londyńskim. Polegało to na sprzedaży złota, gdy cena rynkowa wykazywała tendencję zwyżkową oraz zakupie, gdy spadała (było tylko kilka takich przypadków).

Działania interwencyjne dały pozytywne efekty - cena złota była raczej stabilna. Trzeba jeszcze dodać, że główny ciężar wzięły na siebie USA, które finansowały 50\% wszystkich operacji (Eichengreen 2007: 61).

W 1968 r. presja na wzrost ceny złota była tak silna, że banki centralne postanowiły zaprzestać interwencji i rozwiązać „pool złota”. Od tego czasu w gospodarce światowej zaczęły funkcjonować dwie ceny złota: oficjalna dla 
transakcji między bankami centralnymi (35 USD) i prywatna. Po zawieszeniu wymienialności dolara na złoto (1971 r.) cena oficjalna straciła sens.

W omawianym okresie dokonała się bardzo ważna realokacja złota w gospodarce światowej. Migracja była jednokierunkowa - z USA do Europy. W 1949 r. USA posiadały rezerwy złota o wartości 25 mld USD (cena 35 USD), Europa -5 mld USD. W 1968 r. USA miały już tylko 11 mld USD, Europa - 33 mld USD. Straty w rezerwach złota Stanów Zjednoczonych to koszty sytemu dolarowo-złotego oraz wymienialności dolara na złoto. To również koszty amerykańskiego senioratu walutowego, specjalnego usytuowania dolara w systemie z Bretton Woods. Okazało się, że gdy dolar był ograniczony tzw. kotwicą złota, koszty senioratu mogą przewyższać korzyści (szerzej o senioracie w dalszej części artykułu).

W 1971 r. USA zawiesiły wymienialność dolara na złoto. Zlikwidowano kotwicę, która nakładała na walutę amerykańską obligacje wynikające z systemu dolarowo-złotego. Stany Zjednoczone i MFW rozpoczęły intensywny proces demonetaryzacji złota, tj. wyprzedaż złota z rezerw MFW. Fundusz na aukcjach i w ramach tzw. sprzedaży restytucyjnej pozbył się 1/3 swoich zasobów złota (ok. $50 \mathrm{mln}$ uncji) ${ }^{3}$. W ten sposób demonstrowano zmianę podejścia do złota, kwestionowano nawet jego rolę jako aktywu rezerwowego. Złoto miało stać się normalnym towarem. W warstwie werbalnej kraje Zachodu wspierały proces rugowania złota z systemu, jednak w rzeczywistości utrzymywano lub zwiększano swoje rezerwy złota.

\subsection{Perspektywy złota we wspólczesnych finansach międzynarodowych}

Ostatnie 30 lat charakteryzują trzy procesy odnoszące się do złota:

- „prywatyzacja złota” - rozwój prywatnych rynków złota (Londyn, Zurych, Nowy Jork, Hongkong i inne),

- porozumienie banków centralnych państw strefy euro w sprawie oddziaływania na cenę złota,

- zmiana podejścia MFW w sprawie roli złota w polityce Funduszu.

Rozwój prywatnych rynków złota upodobnił je do rynków finansowych. Zawierane tu są transakcje rzeczywiste (dominuje Zurych) oraz instrumentami pochodnymi (Nowy Jork, Londyn). Najczęściej wykorzystywane są transakcje forward, futures i kontrakty opcyjnie.

Nowym zjawiskiem na międzynarodowych rynkach złota jest pojawienie się banków centralnych jako regulatorów cen złota. W pewnym sensie przypomina to ,pool złota” z lat 60. W 1999 r. w Waszyngtonie 15 banków centralnych i EBC podpisało porozumienie - Central Bank Gold Agreement (CBGA) ${ }^{4}$. Nie ma ono

\footnotetext{
${ }^{3}$ Sprzedaż restytucyjna jest to sprzedaż złota krajom członkowskim w wysokości ich wkładu w złocie do Funduszu po cenie oficjalnej, tj. 25 SDR za uncję.

${ }^{4} \mathrm{~W}$ większości kraje obecnej strefy euro.
} 
charakteru obligatoryjnego, jednak członkowie CBGA przestrzegają ustalonych reguł. Dotyczą one następujących spraw:

- złoto zostało uznane za ważny składnik rezerw światowych,

- wprowadzono limit sprzedaży złota przez poszczególne banki na poziomie 400 ton rocznie (łącznie sprzedaż 2000 ton),

- zobowiązano się do niezwiększania zaangażowania banków centralnych w transakcje terminowe na rynku złota ${ }^{5}$.

Do tej pory zawarto trzy pięcioletnie porozumienia, w których wprowadzono następujące limity sprzedaży:

- $1999-400$ ton rocznie,

- $2004-500$ ton rocznie,

- $2009-400$ ton rocznie.

Zainteresowanie krajów strefy euro i EBC utrzymywaniem stabilnie wysokiej ceny złota wynika z faktu, że podczas gdy wszystkie kraje świata przechowują rezerwy w złocie średnio na poziomie ok. $10 \%$ ogólnego stanu rezerw, to w krajach strefy euro i EBC złoto stanowi 56\% ogólnych rezerw. Znaczenie ceny złota jest zatem oczywiste. Wielkość rezerw złota i ich rozmieszczenie w świecie ilustruje tab. 1.

Tabela 1

Poziom oficjalnych aktywów rezerwowych (mld SDR)

\begin{tabular}{|l|l|r|r|r|r|r|r|r|}
\hline \multicolumn{2}{|c|}{ Poziom rezerw } & 2007 & 2008 & 2009 & 2010 & 2011 & 2012 & $\begin{array}{c}\text { marzec } \\
2013\end{array}$ \\
\hline \multicolumn{2}{|c|}{1} & 2 & 3 & 4 & 5 & 6 & 7 & 8 \\
\hline 1. & Wszzystkie rezerwy bez złota & 4275,1 & 4813,4 & 5447,4 & 6264,4 & 6938,8 & 7419,8 & 7687,9 \\
\hline 2. & Ilość złota w milionach uncji & 855,5 & 856,5 & 879,2 & 884,9 & 897,2 & 911,5 & 915,1 \\
\hline 3. & $\begin{array}{l}\text { Wartość złota według ceny } \\
\text { rynku londyńskiego }\end{array}$ & 451,4 & 483,6 & 609,9 & 807,6 & 894,7 & 986,8 & 976,3 \\
\hline 4. & Łącznie rezerwy ze złotem & 4726,4 & 5297,1 & 6057,2 & 7072,0 & 7833,5 & 8406,6 & 8664,3 \\
\hline & \multicolumn{7}{|c|}{ Rozwinięte gospodarki } \\
\hline 1. & Wszystkie rezerwy bez złota & 1562,9 & 1650,0 & 1929,8 & 2172,2 & 2414,5 & 2605,2 & 2651,5 \\
\hline 2. & Ilość złota w milionach uncji & 716,5 & 707,8 & 704,3 & 704,1 & 705,2 & 706,0 & 706,6 \\
\hline 3. & $\begin{array}{l}\text { Wartość złota według ceny } \\
\text { rynku londyńskiego }\end{array}$ & 378,0 & 399,7 & 488,6 & 642,6 & 703,2 & 764,4 & 753,9 \\
\hline 4. & Łącznie rezerwy ze złotem & 1941,0 & 2049,7 & 2418,3 & 2814,8 & 3117,8 & 3369,6 & 3405,4 \\
\hline
\end{tabular}

${ }^{5}$ Przede wszystkim chodzi o transakcje forward zawierane miedzy bankami centralnymi a podmiotami rynkowymi. Motywem tych transakcji jest finansowanie kosztów przechowywania złota przez banki centralne. 
Tab. 1 (cd.)

\begin{tabular}{|l|l|r|r|r|r|r|r|r|r|}
\hline \multicolumn{2}{|c|}{1} & \multicolumn{1}{|c|}{2} & \multicolumn{1}{|c|}{3} & 4 & 5 & 6 & 7 & 8 \\
\hline \multicolumn{2}{|c|}{ Rynki wschodzące i gospodarki rozwijające się } \\
\hline 1. & Wszystkie rezerwy bez złota & 2712,2 & 3163,4 & 3517,6 & 4092,1 & 4524,3 & 4814,6 & 5036,5 \\
\hline 2. & Ilość złota w milionach uncji & 139,0 & 148,7 & 174,9 & 180,9 & 192,0 & 205,5 & 208,4 \\
\hline 3. & $\begin{array}{l}\text { Wartość złota według ceny } \\
\text { rynku londyńskiego }\end{array}$ & 73,3 & 83,9 & 121,3 & 165,1 & 191,5 & 222,4 & 222,4 \\
\hline 4. & Lącznie rezerwy ze złotem & 2785,5 & 3247,4 & 3638,9 & 4257,2 & 4715,8 & 5037,0 & 5258,8 \\
\hline
\end{tabular}

Źródło: opracowanie własne na podstawie http://www.imf.org/external/pubs/ft/ar/2013/eng/pdf/ a1.pdf (dostęp:10.09.2014).

Dane przedstawione w tab. 1 wskazują na wyraźną koncentrację rezerw złota w gospodarkach uprzemysłowionych. W 2013 r. było to 77\% ogółu rezerw złota monetarnego. Dynamikę zmian proporcji w ostatnich latach między rezerwami w złocie a rezerwami w walutach wymienialnych ilustrują rys. 1-3.

Bardzo gwałtowny wzrost cen złota sprawił, że dynamika przyrostu rezerw w złocie przewyższa dynamikę aktywów rezerwowych w walutach wymienialnych. Wzrost zainteresowania europejskich banków centralnych i MFW ceną złota oraz pełnieniem przez złoto funkcji aktywu rezerwowego rodzi pytanie o przyszłość żółtego kruszcu w międzynarodowym systemie walutowym. Niekiedy pytanie to formułowane jest następująco: czy możliwe jest reaktywowanie goldstandardu lub powtórne powiązanie dolara ze złotem?

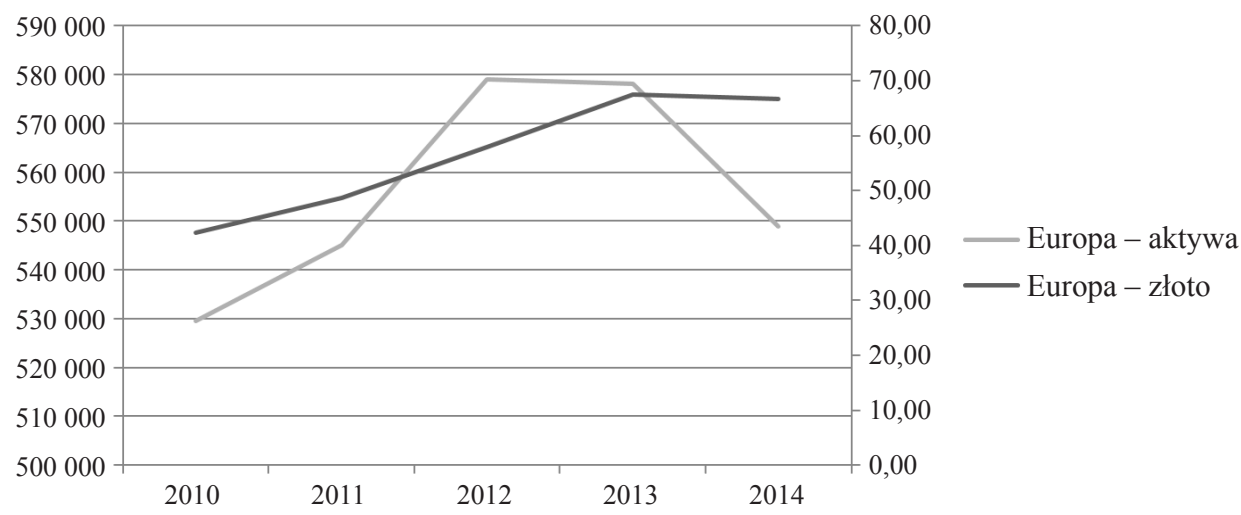

Rys. 1. Dynamika zmian między rezerwami w złocie a rezerwami w walutach - Europa

Źródło: opracowanie własne na podstawie International Financial Statistics IMF, Official Reserve Assets, Foreign Currency Reserves (in Convertible Foreign Currencies), 2014. 


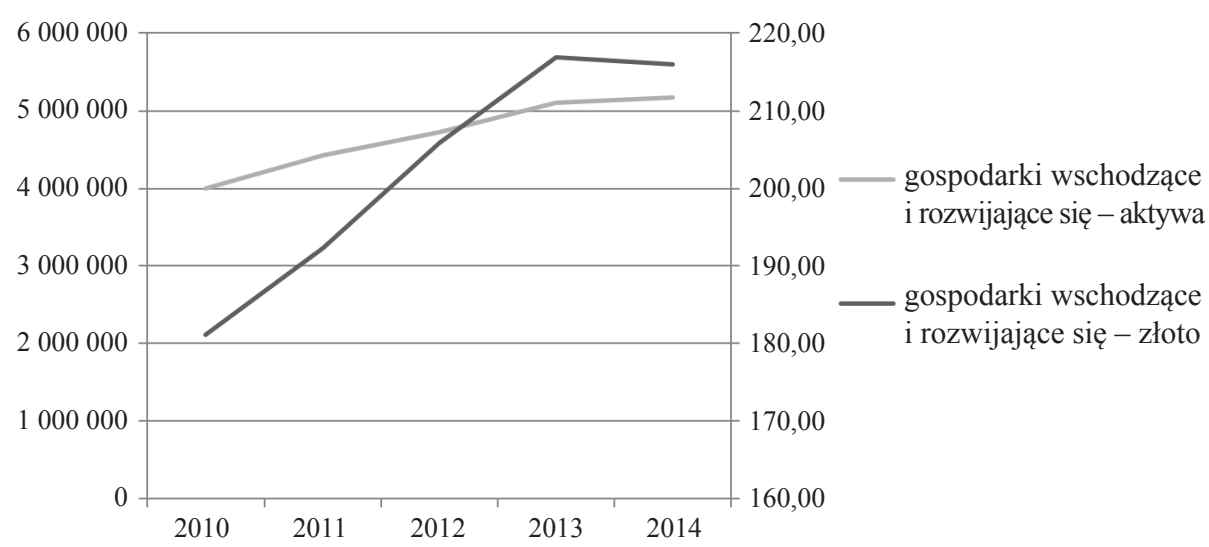

Rys. 2. Dynamika zmian między rezerwami w złocie a rezerwami w walutach - gospodarki wschodzące i rozwijające się

Źródło: jak do rys. 1.

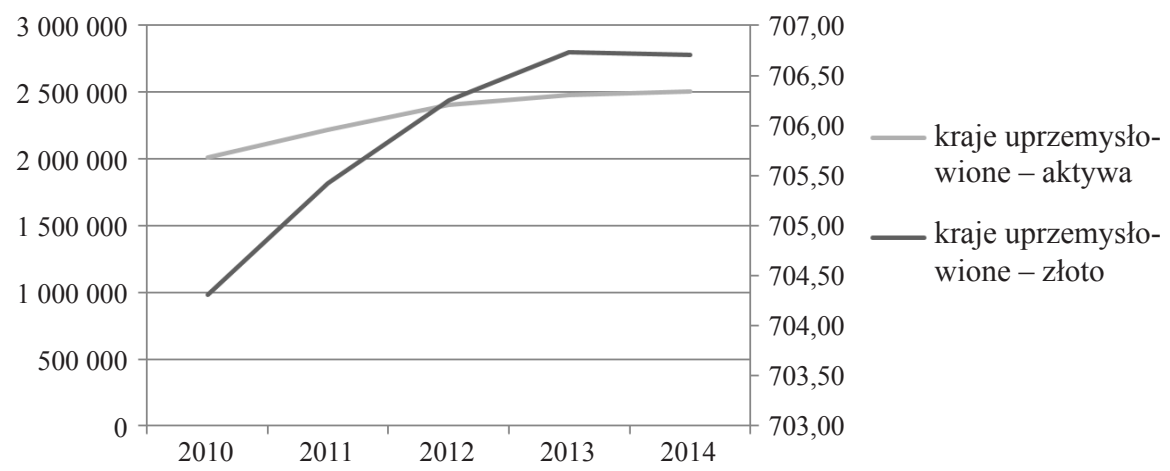

Rys. 3. Dynamika zmian między rezerwami w złocie a rezerwami w walutach - kraje uprzemysłowione

Źródło: jak do rys. 1.

Zwolennicy takich rozwiązań uważani są przez ogół ekonomistów i polityków za monetarnych ekscentryków. Opinii tej nie zmienia fakt, że wśród nich jest kilku noblistów (np. F. A. von Hayek, R. Mundell) lub praktyków - finansistów (wieloletni szef Fed - Alan Greenspan) ${ }^{6}$. Ciekawą pracę na temat perspektyw goldstandardu, zatytułowaną Austriacy o standardzie złota, wydał w Polsce

\author{
70. i 80 .
}

${ }^{6}$ Prawdą jest, że wielu rzeczników reaktywowania goldstandardu zmieniło zdanie w latach 
Instytut Ludwiga von Misesa (Rockwell 2011). Wnioski wynikające z badań są jednoznaczne - nie ma możliwości ponownego utworzenia systemu waluty złotej.

Do podobnych konkluzji doszedł T. Gruszecki, badając różne scenariusze przywrócenia złotu podstawy systemu (Gruszecki 2011: 1 i n.). Autor analizował techniczną możliwość tzw. pokrycia złotem ogólnoświatowego M3. Światowe PKB wynosi 60-70 bln USD, na tyle też szacowany jest globalny agregat M3. Całe złoto świata wynosi 160 tys. ton. Gruszecki przyjął ceny złota z 2010 r. i otrzymał wartość złota na poziomie 5-6 bln USD. Aby otrzymać $100 \%$ pokrycia złotem M3, cena uncji powinna wynosić 10000 USD. Jeżeli analizujemy tylko pokrycie emisji dolara USA, cena wynosiłaby ok. 3000 USD. W oparciu o przedstawioną skrótowo analizę, Gruszecki doszedł do wniosku, że reaktywowanie goldstandardu jest dziś niemożliwe.

\section{DOLAR A POWOJENNE KONCEPCJE PIENIĄDZA MIĘDZYNARODOWEGO}

\subsection{Dyskusja między F. A. von Hayekiem a J. M. Keynesem}

Moim zdaniem prace trzech ekonomistów zdecydowały o powojennym kształcie międzynarodowych stosunków walutowych i stworzyły podłoże intelektualne dla rozwoju idei pieniądza międzynarodowego. Jednym z wielkich i chyba najbardziej znanym był J. M. Keynes. Pierwsza wersja koncepcji światowej unii walutowej, nazywanej skromniej Unią Clearingową, powstała w 1941 r. Ostatnia, czwarta, to oficjalny dokument rządu brytyjskiego na konferencji w Bretton Woods w 1943 r. (Keynes 1969: 2-37).

Drugim ekonomistą - wizjonerem, którego poglądy na temat międzynarodowego sytemu walutowego stają się po kilkudziesięciu latach coraz bardziej aktualne, był F. A. von Hayek. Uważał on, że dla stabilności gospodarki światowej lepszym rozwiązaniem jest funkcjonowanie niezależnych walut narodowych (systemów pieniężnych) niż jednego międzynarodowego sytemu monetarnego (Hayek 1978; Hayek 1937). W opinii wielu właśnie dyskusja między Keynesem a Hayekiem zrodziła współczesną ekonomię. Fragment tej polemiki, dotyczący finansów międzynarodowych, zostanie przedstawiony w dalszej części artykułu.

Jest rzeczą paradoksalną, że najmniej znany z prezentowanej trójki ekonomistów, Johan H. Williams, autor i popularyzator koncepcji waluty kluczowej (key currency), doczekał się realizacji swojego projektu w ramach amerykańskiego Planu White'a (Ussher 2009).

Prezentując dyskusję na temat pieniądza międzynarodowego i organizacji światowego systemu walutowego sprzed ponad 70 laty, można narazić się na zarzut, że wnioski wynikające $\mathrm{z}$ tych analiz będą miały wartość historyczną. Ponadto istnieje ryzyko nadużycia polegające na tym, że „ekonomiczna przeszłość” jest analizowana przy pomocy współczesnych instrumentów badawczych. Ko- 
mentarze i interpretacje dokonywane są przez pryzmat współczesnych wydarzeń w świecie finansów międzynarodowych.

Mimo tych zagrożeń istnieją ważne powody, dla których należy badać dyskusje toczone przez ekonomistów w latach 40 . na temat pieniądza międzynarodowego. Po pierwsze, mechanizmy współczesnych finansów międzynarodowych, ze swoimi wadami i zaletami, są w dużej części efektem decyzji podejmowanych kilkadziesiąt lat temu. Po drugie, lepsze zrozumienie „ekonomicznej przeszłości” powoduje, iż więcej wiemy o „ekonomicznej teraźniejszości”.

Wracając do kontrowersji w poglądach ekonomicznych Keynesa i Hayeka, należy stwierdzić, że różnili się oni niemal we wszystkim. Szkoła austriacka i keynesism to dwa bieguny ekonomii, dwie wizje powojennych finansów międzynarodowych. Wizje te wynikają z logiki dwóch doktryn ekonomicznych, są ich konsekwencją. Oto najważniejsze różnice ${ }^{7}$ :

$\mathbf{1 / K}$ - Keynes zaproponował utworzenie międzynarodowej unii walutowej (clearingowej) ze wspólną jednostką pieniężną - bankorem. Unia miała być zarządzana przez władze ponadnarodowe.

1/H - Hayek uważał tworzenie międzynarodowego systemu walutowego za błąd, natomiast bezpiecznym rozwiązaniem miało być funkcjonowanie wielu walut międzynarodowych oraz konkurencja między nimi. Na poziomie krajowym proponował ,prywatyzacje” pieniądza (nazywane przez Hayeka denacjonalizacją).

2/K - Ważnym elementem planu Keynesa jest kontrola podaży pieniądza w skali międzynarodowej przez Unię Clearingową.

2/H - Hayek był przekonany, że podaż pieniądza reguluje samoczynny mechanizm rynkowy.

3/K - Keynes przewidywał dla bankora kluczową rolę w przyszłym systemie walutowym. Bankor miał być numeraire światowego mechanizmu kursowego (wszystkie waluty miały kurs wyznaczony do tej jednostki), kwoty przyznane poszczególnym krajom miały być denominowane w bankorach. Pełnienie przez bankora funkcji monetarnych oznacza, że Unię Clearingową można w jakimś stopniu porównać z międzynarodowym bankiem centralnym, który może pełnić rolę międzynarodowego pożyczkodawcy ostatniej instancji.

3/H - Hayek proponował pełną wolność walutową, swobodę wyboru waluty transakcyjnej, lokacyjnej i innych. Tworzenie pieniądza lub jednostki europejskiej uważał za utopię. Ponadnarodowe zarządzanie monetarne jest złem, które ze swej istoty jest korupcjogenne.

4/K - W planie Unii Clearingowej złoto zajmowało bardzo ważną pozycję. Keynes przewidywał następujące funkcje złota w systemie: 1) miernik wartości (w oryginale: standard of value); wartość bankora jest definiowana w złocie, tak więc pośrednio wszystkie waluty unii miały kurs wyznaczany w złocie; 2) składnik rezerw; 3) częściowo środek płatniczy.

\footnotetext{
${ }^{7}$ Porównanie w oparciu o cytowane wcześniej poglądy Hayeka i Keynesa.
} 
4/H - We wszystkich znanych mi pracach stanowisko Hayeka wobec złota i ewentualnego standardu złota jest ambiwalentne; co istotne, niewiele zmieniło się w ciągu dziesięcioleci. 1937 r. w Monetary Nationalism and International Stability Hayek pisał, że nie zna poważnych argumentów, które uzasadniałyby reaktywowanie standardu złota. Można znaleźć natomiast wiele racji przeciwko użyciu złota jako pieniądza międzynarodowego. Równocześnie ekonomista ten uważał, że jedynym, w gruncie rzeczy, decydującym argumentem, dlaczego złoto jest najlepszym z możliwych pieniędzy światowych, jest jego uniwersalność i powszechna akceptacja. Hayek był przeciwnikiem tworzenia międzynarodowych jednostek walutowych. W 1976 r. w Denationalization of Money Hayek (1978: 127) pisał, że system waluty złotej nie jest rozwiązaniem na przyszłość (podobnie jak reżim kursów stałych). Równocześnie uważał, że tak długo, jak rządy administrują pieniądzem w skali krajowej i międzynarodowej, standard złoty jest jedynym bezpiecznym systemem, uwzględniając wszystkie jego wady.

Ani plan Keynesa, ani koncepcje Hayeka nie stały się podstawą tworzenia powojennego sytemu walutowego. Nie oznacza to, że politycy zapomnieli o koncepcjach wybitnych ekonomistów. Elementy planu Keynesa często powracały w dyskusjach dotyczących reformy międzynarodowego systemu walutowego - wystarczy tu wskazać utworzenie SDR. Ewolucja finansów międzynarodowych, rola rynków (dzisiejszy międzynarodowy „,non system”) przyznają w wielu aspektach rację Hayekowi. W jakich obszarach austriacki noblista trafnie prognozował rozwój finansów międzynarodowych?

1. Zakładał on, że najlepszym rozwiązaniem jest współistnienie wielu konkurujących ze sobą walut, które byłyby uwolnione od manipulowania nimi przez rządy państw. Dziś na światowych rynkach walutowych wiodącą rolę odgrywa 5-6 walut, a jeżeli uwzględnić regiony, to ich liczba zwiększy się do 10 walut. Możliwości bezpośredniego oddziaływania na te waluty przez narodowe władze monetarne są ograniczone; proces eksterioryzacji spowodował, że ich wartość kształtuje działanie sił rynkowych na poziomie międzynarodowym.

2. Keynes i wielu ekonomistów uważało oraz nadal uważa, iż podaż pieniądza międzynarodowego (pieniędzy międzynarodowych) musi być kontrolowana bądź przez bank centralny emitujący walutę światową, bądź przez międzynarodową organizację finansową (np. MFW). Warto podkreślić, że od połowy lat 70 . upowszechnił się pogląd, iż w gospodarce światowej działa bliżej niezidentyfikowany mechanizm, który przez zmiany w krajowych poziomach płynności dostosowuje jej podaż do potrzeb gospodarki światowej (Bilski 2006: 124).

3. Trzecim obszarem potwierdzającym trafność prognoz Hayeka są kursy walutowe. Upowszechnienie się kursów płynnych dowodzi, że Hayek miał rację.

${ }^{8} \mathrm{O}$ tym, że mechanizm ten nie działa niezawodnie przekonaliśmy się w czasie kryzysu finansowego 2008/2010, kiedy to Fed wziął na siebie obowiązki pożyczkodawcy ostatniej instancji i dostarczał dolary największym bankom centralnym świata. 


\subsection{Koncepcja waluty kluczowej}

Dyskusje między Keynesem a Hayekiem wykraczały poza ówczesną „ekonomiczną teraźniejszość". Idee te kreowały nowe kierunki rozwoju finansów międzynarodowych, nie uwzględniając jednak (lub czyniąc to w niewielkim stopniu) realiów gospodarczych po II wojnie światowej.

W połowie lat 40. XX w. było już wiadomo, że Stany Zjednoczone będą dominowały w gospodarce światowej przez najbliższe dziesięciolecia. Dolar nie miał alternatywy na światowym rynku finansowym. Musiał powstać hierarchiczny międzynarodowy system walutowy oparty na dolarze. Należy zatem przyjąć, że koncepcja key currency, która pojawiła się w tym czasie w literaturze ekonomicznej, stanowi właściwie opis realnej sytuacji w finansach międzynarodowych lat 40 .

John W. Williams zaproponował w 1943 r. (Ussher 2009: 408), aby powojenny system walutowy oprzeć na walucie kluczowej - dolarze, który zastąpiłby złoto i funta szterlinga. Key currency był dobrym rozwiązaniem z punktu widzenia rozliczeń oraz inwestycji międzynarodowych. Powszechna akceptacja key currency sprawiła, że finanse międzynarodowe mają jednolity standard monetarny dla wszelkiego rodzaju transakcji międzynarodowych.

Współczesna literatura ekonomiczna formułuje kilka warunków, jakie musi spełnić gospodarka emitująca walutę międzynarodową (kluczową):

1. Jest to waluta kraju dominującego w gospodarce światowej.

2. Rynek finansowy kraju jest znaczących rozmiarów, o dużej płynności i wysokim stopniu liberalizacji.

3. Waluta charakteryzuje się stabilną wartością w czasie i jest powszechnie akceptowana.

4. Gospodarka jest w stanie zaspokoić popyt na płynność międzynarodową i rezerwy walutowe.

Gdyby powyższe warunki odnieść do realiów drugiej połowy lat 40., to nie ma wątpliwości, że tylko gospodarka amerykańska je spełniała.

Kiedy po II wojnie światowej wykształcał się system oparty na walucie kluczowej, ekonomiści i politycy zaczęli zadawać następujące pytania:

- czy key currency może być tylko jedna?

- czy możliwe jest funkcjonowanie finansów międzynarodowych z dwiema, trzema walutami kluczowymi?

Pytania formułowane w latach 40. i 50. stają się coraz bardziej aktualne na początku XXI w. Wielu ekonomistów uważa, że system wielodewizowy, który wykształcił się w latach 70. oznacza, iż w praktyce mamy do czynienia z kilkoma walutami kluczowymi. Na przykład K. Zabielski sądził, że istotą systemu jest pełnienie przez wiele walut funkcji pieniądza międzynarodowego (Zabielski 1999: 51)9.

9 Mam świadomość, że K. Zabielski pisze o walutach międzynarodowych, a nie kluczowych, nie zmienia to jednak faktu, że w założeniach systemu wielodewizowego opierał się na kilku-kilkunastu walutach dominujących. 
Zdecydowanie odmiennego zdania jest B. Eichengreen i cytowany przez niego A. Persaud (Eichengreen 2011: 129). Eichengreen zbadał relacje między funtem a dolarem w ujęciu historycznym, ocenił perspektywy wspólistnienia dolara i euro oraz doszedł do wniosku, że waluta kluczowa może być tylko jedna. Zwrócił jednak uwagę na fakt, że niektóre funkcje monetarne mogą być pełnione w znaczącym zakresie przez inne waluty. I tak według Eichengreena funkcję aktywu rezerwowego czy waluty fakturowania handlu mogą pełnić pieniądze innych państw.

Podzielam tu pogląd B. Eichengreena, a przeprowadzone przez niego badania dotyczące pełnienia przez dolara i euro funkcji monetarnych w ostatnich dziesięcioleciach potwierdzają te wnioski (Bilski 2012). Euro stało się znaczącym konkurentem dla dolara w funkcji aktywu rezerwowego w sferze oficjalnej (w $2009 \mathrm{r}$. ok. 28\%), fakturowania handlu, a nawet miernika wartości. Widoczna jest jednak bezwzględna dominacja dolara w funkcji składnika płynności międzynarodowej, waluty lokacyjnej czy waluty przejścia. Pokazuje to, że finanse międzynarodowe potrzebują jednolitego standardu monetarnego.

System waluty kluczowej opartej na dolarze działał sprawnie do drugiej połowy lat 60. - wtedy to pojawiły się pierwsze symptomy nadciągającego kryzysu. Grupa ekonomistów podjęła próbę przygotowania nowych rozwiązań dla międzynarodowego systemu walutowego.

\subsection{Waluta rezerwowa oparta na towarach (Commodity Reserve Currency - CRC)}

Koncepcja CRC powstała na początku lat 60. Rozwinięta wersja projektu przedstawiona została na I Konferencji UNCTAD w 1964 r. przez A. G. Harta, N. Kaldera i J. Tinenbergena (Drabowski 1988: 252). Koncepcja pieniądza międzynarodowego oparta na towarach to reakcja autorów na, ich zdaniem, wadliwe działanie systemu key currency opartego na dolarze. Projekt CRC miał zapewnić:

- kontrolę nad podażą pieniądza międzynarodowego (dylemat Triffina) (Ussher 2009: 405),

- stworzenie waluty międzynarodowej o stabilnej wartości i niezależnej od USA,

- osiąganie równowagi globalnej w szczególności miedzy krajami centrum i peryferii (uprzemysłowione - rolnicze).

Podstawowym założeniem projektu jest konstrukcja koszyka, który definiowałby wartość CRC. Koszyk powinien składać się z ok. 30 towarów charakteryzujących się wysokim stopniem standaryzacji i trwałością. Wahania cen poszczególnych towarów w niewielkim stopniu będą przekładały się na wahania CRC, ponieważ ulegają one uśrednieniu.

Administratorem wspólnego pieniądza miał być MFW, który również zarządzałby zgromadzonymi rezerwami towarów. „Pokrycie towarowe” CRC tworzyłyby towary i złoto w następujących proporcjach: np. 30-miliardowa (USD) emi- 
sja CRC byłaby w 20 mld pokryta towarami, w 5 mld złotem i 5 mld bez pokrycia (Drabowski 1988: 213).

Ważną kwestię stanowił zakres cyrkulacji CRC i zasady jej podaży. N. Kaldor oraz pozostali autorzy projektu zakładali, iż pieniądz towarowy będzie wykorzystywany tylko w obiegu międzynarodowym. CRC miała parytet wyznaczony w złocie, a zadaniem MFW miało być działanie na rzecz stabilizacji wartości waluty.

Jako waluta międzynarodowa, CRC miała pełnić funkcje denominatora mechanizmów kursowych, składnika rezerw i środka płatniczego (raczej w sferze oficjalnej).

Kreacja CRC może mieć miejsce w następujących przypadkach:

- na poziomie MFW może to być autonomiczna decyzja Funduszu; w przypadku stwierdzenia niedoboru płynności w skali światowej wiązało się to z koniecznością zwiększenia przez MFW rezerw złota lub towarów,

- na poziomie krajowym poszczególne państwa mogły nabywać CRC od Funduszu w zamian za złoto lub rezerwy towarowe.

Ważnym elementem projektu było założenie, że MFW będzie interweniowało na rynkach surowcowych w celu stabilizowania ich cen. To stworzy dogodne warunki dla rozwoju krajów rolniczych, dla których wahania cen surowców i płodów rolnych są istotnym zagrożeniem.

Kiedy dziś, z perspektywy 50 lat, patrzymy na plan Kaldora, wyraźnie widać sprzeczności między założeniami CRC a ewolucją finansów międzynarodowych. Kaldor w swym projekcie zakładał, iż procesy dokonujące się w gospodarce realnej będą miały główny wpływ na międzynarodowe stosunki walutowe. We współczesnej gospodarce światowej jest odwrotnie - to ceny aktywów finansowych oraz przepływy kapitałów decydują o poziomach kursów walutowych, pozycji waluty międzynarodowej.

Czy oznacza to, że projekt CRC skazany jest na zapomnienie i nie ma szans na praktyczną realizację? Nie sądzę. Koncepcja Kaldora może być jedynym ratunkiem w przypadku głębokiego kryzysu systemu opartego na dolarze. Jeżeli gospodarka światowa nie wykształci innych walut międzynarodowych, które będą mogły przejąć funkcje dolara (euro jeszcze nie dojrzało do tej roli), to pozostaje tylko pieniądz oparty na towarach.

Interesujący jest jednak fakt, że we współczesnej ekonomii pojawiają się projekty, które zakładają wykorzystanie pieniądza towarowego. Jako przykład można tu podać sposób definiowania wspólnego pieniądza „Europy” w projekcje integracji monetarnej opartej na walucie paralelnej (The All Saints'day manifesto... 1975).

\subsection{Seniorat walutowy}

Funkcjonowanie w międzynarodowym systemie walutowym różnych form pieniądza międzynarodowego wiąże się z problemem senioratu walutowego. Polega on na specjalnym usytuowaniu i wynikających z tego korzyściach dla kraju 
emitującego walutę kluczową. Zjawisko to było przedmiotem licznych sporów o charakterze polityczno-publicystycznym. Ekonomiści i politycy europejscy do niedawna zarzucali USA, że exorbitant privilege zakłóca równowagę w skali globalnej, tworząc dla gospodarki amerykańskiej nadzwyczajne korzyści. Dziś, gdy od prawie 15 lat funkcjonuje w Europie wspólny pieniądz, tj. euro, problem senioratu nie budzi już takich namiętności. Jest to zrozumiałe, biorąc pod uwagę fakt, że strefa euro jest beneficjentem europejskiego seigniorage.

W ostatnich latach pojawiły się w literaturze ekonomicznej pierwsze próby kwantyfikowania zysku z senioratu walutowego. Wyniki badań wskazują na raczej umiarkowane korzyści dla państw emitujących pieniądz światowy (waluty międzynarodowe). Ponadto rozpoczęto badania nad kosztami i zagrożeniami dotykającymi kraju o walucie dominującej w gospodarce światowej (dotyczy to USA).

W tej części artykułu podjęta będzie próba oceny, czy koszty szczególnej roli dolara $\mathrm{w}$ finansach międzynarodowych nie przewyższają korzyści wynikających z senioratu. Sądzę, że w usytuowaniu waluty amerykańskiej w światowym systemie walutowym zawarty jest pewien element autodestrukcji waluty kluczowej. Obligacje nakładane przez mechanizmy systemu na walutę światową wpływają negatywnie na jej kondycje.

Analizę wad i zalet senioratu walutowego należy rozpocząć od zdefiniowania samego pojęcia. Termin ,seniorat walutowy” (ang. seigniorage) pochodzi z wieków średnich i oznacza prawo bicia własnej monety (srebrnej lub złotej) przez księcia (seniora). Większość autorów zajmujących się omawianą problematyką jest zdania, że średniowieczny zysk mennicy to dzisiejszy seniorat walutowy. Mincerzy produkujący monety na potrzeby księstwa zarabiali na różnicy pomiędzy wartością kruszcu w monecie a jego wartością na rynku, potwierdzoną stemplem monarchy i kursem przymusowym. Co ciekawe, zysk menniczy mógł być realizowany kilka razy w roku. I tak np. uważany za specjalistę od „psucia monety” Mieszko Stary przeprowadzał przymusową wymianę monet trzy razy w roku - nazywało się to monete renovatio (Grodecki 2010: 75). Ta nieskomplikowana polityka monetarna Mieszka Starego dawała mu według obliczeń specjalistów zysk menniczy na poziomie ok. $6 \%$ rocznie. Niestety, po 10 latach było to już $60 \%$.

W 1232 r. Krzyżacy wydali rozporządzenie dla Chełmna w sprawie wymiany monet. Miało się to odbywać raz na 10 lat i było konsekwencją ścierania się srebrnych denarów, które stawały się lżejsze. Przy tym, co istotne, wymiana odbywała się w proporcjach: 7 starych za 6 nowych denarów. To była jakby naturalna stopa deprecjacji obowiązującej monety w stosunku do kruszcu (Grodecki 2010: 73).

Dzisiejszy zysk z senioratu walutowego nie jest tak prosty $\mathrm{w}$ interpretacji jak zysk menniczy. Po pierwsze, powstaje on w obrocie międzynarodowym; po drugie zaś, seniorat walutowy oprócz korzyści rodzi również spore zagrożenia dla kraju emitującego walutę kluczową. Definicje seigniorage można podzielić na trzy grupy ze względu na ich zakres pojęciowy: 
1. Najbliższa znaczeniu renty menniczej jest definicja, która interpretuje seniorat jako zjawisko wewnętrzne. J. Williamson warunkuje wystąpienie seigniorage istnieniem monopolu emisji pieniądza, a zysk jest różnicą między wartością pieniądza a kosztami jego produkcji (Truman 2012: 21).

2. B. Eichengreen i E. Drabowski definiują seniorat w ujęciu międzynarodowym. Jest to według Drabowskiego (1986: 233) zysk z emisji pieniądza wykorzystywanego w płatnościach międzynarodowych. Zysk ten jest określony różnicą miedzy kosztami emisji a wysokością dochodu, za który nabywa się towary i usługi za granicą. Eichengreen precyzyjniej określa seniorat walutowy USA. Uważa, że tak długo, jak banki centralne i inne podmioty rynku będą godziły się zarabiać mniej na lokowaniu wolnych środków w amerykańskie aktywa finansowe, tak długo gospodarka USA będzie realizowała seniorat. Różnica między rentownością aktywów dolarowych zagranicy a inwestycjami finansowymi USA za granicą wynosi ok. 3 pkt procentowe (Eichengreen 2011: 4).

3. Najszerszą interpretację terminu ,seniorat walutowy" zaproponował J. Walmsley (Walmsley 1985: 179). Uważa on, że oprócz korzyści przedstawionych w definicjach E. Drabowskiego i B. Eichegreena, seigniorage oznacza kontrolę nad stopami procentowymi oraz warunkami działania rynku walutowego, co jest równoznaczne $\mathrm{z}$ dyktowaniem ceny pieniądza światowego ${ }^{10}$.

Szacowanie korzyści wynikających z senioratu walutowego dokonuje się najczęściej w oparciu o definicje Eichengreena i Drabowskiego. Jest to zrozumiałe, gdyż opis Walmsleya zawiera zbyt dużo elementów niemierzalnych.

Poniżej zamieszczona jest kalkulacja senioratu dokonana przez E. M. Trumana, który wykorzystał istniejący dorobek badawczy w tej dziedzinie (Truman, Fellow 2012). Zidentyfikował on i oszacował dwa źródła powstawania zysku $\mathrm{z}$ senioratu ${ }^{11}$.

Pierwsze wiąże się z faktem, że ok. 40 do $65 \%$ całkowitej emisji dolarów cyrkuluje i jest przechowywane za granicą. W 2011 r. było to od 414 do 672 mld USD. To efekt tzw. dolaryzacji (oficjalnej i nieoficjalnej) gospodarek wielu państw świata. Jest to nieoprocentowane zadłużenie USA. E. M. Truman przyjął, że oprocentowanie amerykańskich papierów skarbowych wyniosło średnio w ostatnich latach 3,62\%, co daje oszczędności dla gospodarki amerykańskiej od 15 do 24 mld rocznie - jest to zysk z senioratu. Dla strefy euro seniorat wyniósł od 8 do 10 mld EUR.

Drugim źródłem przychodu z senioratu jest pełnienie przez dolar funkcji aktywu rezerwowego. Banki centralne przechowujące rezerwy w dolarach w rzeczywistości nabywają aktywa amerykańskie denominowane w dolarach i oprocentowane od 30 do 200 pkt bazowych niżej od poziomu rynku. Pieniądze

${ }^{10}$ Uważa się, że cenę pieniądza światowego i oprocentowanie określa trzymiesięczny LIBOR na dolara na rynku europejskim (eurodolarowym).

${ }^{11}$ Badanie dotyczyło dolara i pozostałych głównych walut świata (euro, funta i innych). 
uzyskane ze sprzedaży zagranicznym inwestorom papierów skarbowych mogą być przeznaczone na finansowanie amerykańskiego długu publicznego (gross general government debt).

E. M. Truman przeprowadził następującą kalkulację. W 2011 r. dolary stanowiły $62,2 \%$ oficjalnych rezerw walutowych świata, tj. 6,34 bln USD. Zadłużenie wyniosło w tymże roku 15,53 bln dolarów, co oznacza, że ok. 40\% długu mogło być finansowane przy oprocentowaniu niższym o 30 pkt bazowych od oprocentowania rynku amerykańskiego - ten zysk to seniorat, który w badanym roku wyniósł 46,6 mld USD.

Podobne kalkulacje E. D. Truman przeprowadził dla wszystkich głównych walut świata. Ilustruje to tab. 2.

Tabela 2

Seniorat walutowy wynikający z wykorzystywania dolarów i innych walut w funkcji aktywa rezerwowego w latach 1999, 2006 i 2011 (efekt liczony przy założeniu 30 pkt bazowych)

\begin{tabular}{|c|c|c|c|c|c|c|}
\hline Kraj/region & $\begin{array}{c}\text { Udział \% } \\
\text { w globalnych } \\
\text { rezerwach } \\
\text { walutowych }\end{array}$ & $\begin{array}{l}\text { Rezerwy } \\
\text { w mld } \\
\text { USD }\end{array}$ & $\begin{array}{c}\text { Dług } \\
\text { publiczny } \\
\text { brutto } \\
\text { [mld USD] }\end{array}$ & $\begin{array}{l}\text { Rezerwy/ } \\
\text { długi [\%] }\end{array}$ & $\begin{array}{c}\text { Seniorat } \\
\text { [mld } \\
\text { USD] }\end{array}$ & $\begin{array}{c}\text { Seniorat } \\
\text { jako \% } \\
\text { GDP }\end{array}$ \\
\hline 1 & 2 & 3 & 4 & 5 & 6 & 7 \\
\hline \multicolumn{7}{|c|}{2011} \\
\hline $\begin{array}{l}\text { Stany } \\
\text { Zjednoczone }\end{array}$ & 62,2 & 6343 & 15537 & 40,1 & 46,6 & 0,31 \\
\hline Strefa euro & 25,0 & 2552 & 11555 & 22,1 & 18,8 & 0,14 \\
\hline $\begin{array}{l}\text { Wielka } \\
\text { Brytania }\end{array}$ & 3,8 & 390 & 1994 & 19,6 & 2,9 & 0,12 \\
\hline Japonia & 3,5 & 359 & 13466 & 2,7 & 2,6 & 0,04 \\
\hline Szwajcaria & 0,1 & 12 & 309 & 3,9 & 0,1 & 0,02 \\
\hline Pozostałe & 5,3 & 539 & b.d. & b.d. & 4,0 & b.d. \\
\hline Razem & 100,0 & 10195 & b.d. & b.d. & 74,9 & b.d. \\
\hline \multicolumn{7}{|c|}{2006} \\
\hline $\begin{array}{l}\text { Stany } \\
\text { Zjednoczone }\end{array}$ & 65,5 & 3440 & 8913 & 38,6 & 25,7 & 0,19 \\
\hline Strefa euro & 25,1 & 1318 & 7374 & 17,9 & 9,9 & 0,09 \\
\hline $\begin{array}{l}\text { Wielka } \\
\text { Brytania }\end{array}$ & 4,4 & 230 & 1056 & 21,8 & 1,7 & 0,07 \\
\hline Japonia & 3,1 & 162 & 8103 & 2,0 & 1,2 & 0,03 \\
\hline Szwajcaria & 0,2 & 9 & 253 & 3,6 & 0,1 & 0,02 \\
\hline Pozostałe & 1,7 & 94 & b.d. & b.d. & 0,7 & b.d. \\
\hline Razem & 100,0 & 5253 & b.d. & b.d. & 39,3 & b.d. \\
\hline
\end{tabular}




\begin{tabular}{|l|r|r|r|r|r|c|}
\hline \multicolumn{1}{|c|}{1} & 2 & 3 & 4 & 5 & 6 & 7 \\
\hline \multicolumn{7}{|c|}{1999} \\
\hline $\begin{array}{l}\text { Stany } \\
\text { Zjednoczone }\end{array}$ & 71,0 & 1255 & 5691 & 22,2 & 9,45 & 0,10 \\
\hline Strefa euro & 17,9 & 319 & 4938 & 6,5 & 2,38 & 0,03 \\
\hline $\begin{array}{l}\text { Wielka } \\
\text { Brytania }\end{array}$ & 2,8 & 51 & 656 & 7,8 & 0,38 & 0,03 \\
\hline Japonia & 6,4 & 114 & 5845 & 2,0 & 0,84 & 0,02 \\
\hline Szwajcaria & 0,2 & 4 & 164 & 2,4 & 0,03 & 0,01 \\
\hline Pozostałe & 1,6 & 28 & b.d. & b.d. & 0,21 & b.d. \\
\hline Razem & 100,0 & 1782 & b.d. & b.d. & 13,31 & b.d. \\
\hline
\end{tabular}

b.d. - brak danych.

Źródło: Truman, Fellow (2012): 51.

Obliczenia przeprowadzone przez E. D. Trumana oparte są na przyjęciu wielu uproszczeń i zastosowaniu w kalkulacji dolnej granicy różnicy w oprocentowaniu wynoszącej 30 pkt bazowych (górna 200 pkt bazowych). To znacząco wpłynęło na wynik, nie zmienia jednak faktu, że wpływ senioratu walutowego na wzrost PKB jest umiarkowany, co podważa wyrażane często opinie o nadzwyczajnych i niezasłużonych zyskach.

Pełnienie przez dolara funkcji waluty kluczowej nakłada na gospodarkę amerykańską określone zobowiązania, które rodzą cały szereg zagrożeń:

1. USA prowadzą pasywną politykę kursową, czego konsekwencją jest przeszacowany kurs dolara do głównych walut świata. B. Eichegreen w cytowanej już pracy przytacza obliczenia wskazujące, że deprecjacja dolara o ok. 10\% skutkowałaby poprawą międzynarodowej pozycji inwestycyjnej USA o ok. $450 \mathrm{mld}$ USD, co jest równoznaczne ze znaczącą poprawą salda rachunków obrotów bieżących (Eichengreen 2010: 5). Wzrost eksportu z pewnością przyczyniłby się do zwiększenia dynamiki PKB.

2. USA prowadzą bardzo liberalną politykę monetarną odnośnie do krajowego rynku finansowego i międzynarodowych przepływów kapitałowych. Import „taniego pieniądza” z zagranicy uruchamia proces „wypychania” oszczędności krajowych. Dostępność finansowania zagranicznego blokuje uruchamianie mechanizmów dostosowawczych, np. w zakresie salda rachunku obrotów bieżących czy deficytu budżetowego, co pozwala gospodarce amerykańskiej ,żyć ponad stan".

3. Pełnienie przez dolara funkcji głównego składnika płynności międzynarodowej, waluty przejścia i lokacyjnej sprawiają, że w czasach kryzysów finansowych USA muszą pełnić funkcję międzynarodowego pożyczkodawcy ostatniej 
instancji (Bilski 2011). Załamanie rynków finansowych z lat 2007-2009 sprawiło, iż finanse międzynarodowe, podobnie jak w latach 50. i 60. zaczęły odczuwać „głód dolarowy”. Fed uruchomił wtedy siatkę swap dla ratowania płynności światowej o łącznej wartości ok. 250 mld USD (jest to wartość nieprecyzyjna, bowiem część banków centralnych miała porozumienie z Fed bez limitu).

Przedstawiona powyżej skrótowa analiza korzyści i kosztów związanych z senioratem walutowym podważa rozpowszechniony pogląd o nadzwyczajnych zyskach kraju emitującego walutę kluczową. Korzyści w ujęciu finansowym są raczej ograniczone, a zagrożenia bardzo realne. Powojenna historia dolara i gospodarki amerykańskiej potwierdza tę opinię.

\section{WNIOSKI}

Przedstawione w artykule analizy upoważniają do sformułowania następujących wniosków:

1. Współczesna nauka nie zaproponowała nowych koncepcji pieniądza międzynarodowego. Dyskusje ekonomistów z lat 40. i 50. są w dalszym ciągu aktualne.

2. Międzynarodowy system walutowy oparty jest na dolarze - walucie kluczowej. Pozostałe „duże” waluty pełnią funkcje walut regionalnych.

3. Ewolucja finansów międzynarodowych zmierza w kierunku wykształcenia się sferycznego systemu walutowego, składającego się z trzech poziomów. Pierwszy tworzy dolar jako waluta kluczowa. Drugim poziomem są waluty międzynarodowe o charakterze regionalnym. Trzecim są waluty pozostałych państw nieaspirujące do pełnienia funkcji międzynarodowych. Taka konstrukcja światowego systemu walutowego staje się coraz bardziej realna $\mathrm{i}$ - co istotne - stanowi efekt działania sił rynkowych.

\section{BIBLIOGRAFIA}

Bilski J. (2006), Międzynarodowy system walutowy. Kierunki ewolucji, PWE, Warszawa.

Bilski J. (2011), Dolaryzacja w gospodarce światowej - przyczyny, rodzaje, „Zeszyty Naukowe Uniwersytetu Ekonomicznego w Poznaniu", nr 179, s. 19-32.

Bilski J. (2012), Proces tworzenia pieniadza międzynarodowego w Europie. Mechanizmy funkcjonowania strefy euro, „Acta Universitatis Lodziensis. Folia Economica”, nr 264, s. 35-51.

Drabowski E. (1986), Międzynarodowe stosunki ekonomiczne i finansowe, PWE, Warszawa.

Drabowski E. (1988), Pieniadz międzynarodowy, PWE, Warszawa.

Eichengreen B. (2007). Global Imbalances and the Lessons of Bretton Woods, MIT Press, Cambridge MA-London.

Eichengreen B. (2011), Exorbitant Privilege, Oxford University Press, New York.

Grodecki R. (2010), Polityka pieniężna Piastów, Wydawnictwo Avalon, Kraków. 
Gruszecki T. (2011), Kryzys międzynarodowego systemu walutowego a spory o pieniadz, Katolicki Uniwersytet Lubelski, maszynopis.

Hayek F. A. (1937), Monetary Nationalism and International Stability, Longman Green, London; przedruk: Augustus M. Kelley Publishers, Fairfield NY 1989.

Hayek F. A (1978), Denationalization of Money, The Institute of Economic Affairs, London.

Homer S., Sylla R. (2005), A History of Interest Rates, $4^{\text {th }}$ ed., John Wiley \& Sons, Hoboken NJ.

Keynes J. M. (1969), Proposal for an International Currency (or Clearing) Union, [w:] J. K. Horsefield (ed.), The International Monetary Found 1945-1965, Vol. III: Documents, International Monetary Fund, Washington.

McCallum B.T. (1996), International Monetary Economics, Oxford University Press, Oxford-New York.

Rockwell L. (red.) (2011), Austriacy o standardzie złota, Instytut Ludwiga von Misesa, Warszawa.

The All Saints' day manifesto for European Monetary Union (1975), "The Economist", 1-7 November.

Truman E. M., Fellow S. (2012), John Williamson and the International Monetary System or "Nonsystem"?, Peterson Institute for International Economics, Washington.

Ussher L. J. (2009), Global Imbalances and the Key Currency Regime: The Case for a Commodity Reserve Currency, "Review of Political Economy", Vol. 21, No. 3, s. 403-421.

Walmsley J. (1985), Macmillan Dictionary of International Finance, Macmillan Press, London.

Williams J. H. (1943), Currency Stabilization: the Keynes and White Plans, "Foreign Affairs", No. 21 (July).

Zabielski K. (1999), Finanse międzynarodowe, PWN, Warszawa.

\section{Janusz Bilski}

\section{INTERNATIONAL CURRENCY IN THE POSTWAR HISTORY OF THE WORLD MONETARY SYSTEM. THEORY AND PRACTICE}

Abstract. This article aims to discuss the idea of nature, forms and mechanisms of international currency. It presents the evolution of the main forms of global currency. Furthermore the benefits and risks coming from the currency seigniorage are studied.

Keywords: goldstandard, dollar, international currency, key currency, international monetary system. 